\title{
Evaluation of different doses of indole-3-butyric acid (IBA) on the rooting, survival and vegetative growth performance of hardwood cuttings of Flordaguard peach (Prunus persica L. Batch)
}

\author{
Sukhjit Kaur \\ Punjab Agricultural University, Regional Research Station, Gurdaspur-143521 (Punjab), INDIA \\ E-mail: sukhi.rose@gmail.com
}

Received: May 22, 2016; Revised received: October 5, 2016; Accepted: January 17, 2017

\begin{abstract}
The present study was conducted on the evaluation of different doses of indole-3-butyric acid (IBA) on the rooting, survival and vegetative growth performance of hardwood cuttings of Flordaguard peach (Prunus persica L. Batch) during the years 2012-13 and 2013-14 at Punjab Agricultural University, Regional Research Station, Gurdaspur. The hardwood cuttings of 10 years old Flordaguard peach plant having $15-20 \mathrm{~cm}$ in length and $0.8-1.2 \mathrm{~cm}$ in diameter with 6-7 buds were prepared in the first fortnight of January .The basal portion of the cuttings was dipped in different doses of IBA viz. 1000ppm, 2000ppm, 3000ppm, 4000pppm, 5000ppm and control (without IBA treatment) for 1-2 minutes and planted in an open field conditions by following the recommended cultural practices for nursery raising. It was noticed that hardwood cuttings of Flordaguard peach treated with 3000ppm of IBA for 12 minutes significantly took the minimum number of days to sprouting (7.05), rooting (6.0) with highest sprouting percentage $(98.45 \%)$, survival percentage $(90.55 \%)$, plant height $(195.45 \mathrm{~cm})$, plant girth $(10.50 \mathrm{~cm})$, number of branches(13.50), number of leaves $(260.4)$, leaf length $(19.55 \mathrm{~cm})$, leaf breadth $(4.12 \mathrm{~cm})$, leaf weight $(2.0 \mathrm{gm})$, percent rooting $(94.45 \%)$, number of roots $(75.83)$, root length $(38.0 \mathrm{~cm})$, root girth $(0.98 \mathrm{~cm})$ and root weight $(13.50 \mathrm{gm})$. Therefore, the application of $3000 \mathrm{ppm}$ IBA was found to be best in terms of rooting, survival and vegetative growth of hardwood cuttings of Flordaguard peach (Prunus persica L. Batch). The beneficial effect of present work develop protocol which can be reliably used to develop the rootstock plant of Flordaguard which is resistant to nematodes through cutting which become ready for budding/grafting in the field in one year instead of two years as raised through seed.
\end{abstract}

Keywords: Indole-3-butyric acid, Hardwood cuttings, Peach, Rooting, Survival, Vegetative growth

\section{INTRODUCTION}

Peach (Prunus persica L. Batch) belongs to family Rosaceae and sub-family Prunoidae is a winter deciduous stone fruit plant and is probably the most adapted temperate fruit to the warmer climate. Besides being cultivated in the temperate climate in the hills, it is also cultivated in the north Indian plains (sub-tropical climate) in the states of Punjab, Haryana, Rajasthan and Uttar Pradesh with the introduction of low chilled peaches. In Punjab, it is grown in an area of 1716 hectares with production of 30340 metric tonnes annually (Annonymous, 2015). Peach is a temperate zone fruit tree but it is possible to grow in the sub-tropical climate of Punjab plains because of availability of suitable low chilling cultivars. In Punjab, about 300 chilling hours are available and the cultivars whose chilling requirement is more than 300 hours shall not grow successfully. Peach cultivation is distributed throughout the state. Sub-tropical climate of Punjab is ideally suited for the cultivation of low chilling peaches (Annonymous, 2010). Peaches are highly valued as a table fruit for their attractive colour and palatability. Fruits contain about 8.0 percent sugar, 0.8 per cent minerals and 1.5 per cent proteins. Peaches can be processed as canned and dried products, frozen preserves, jam, nectar, juice, beverage and marmalade etc. Peaches are also good source of low calorific diet. The peach kernel oil is utilized in manufacturing of large number of cosmetics and pharmaceutical products. The subtropical peaches come in the market early in season (mid-April), growers can get higher returns due to scarcity of other fresh fruits. Its first commercial crop is obtained within three years of planting which is much earlier than majority of other temperate fruits (Annonymous, 2010). Peach trees are generally grown for commercial production as two genetically different components consisting of a scion either budded or grafted to a rootstock. In peaches, seeds of 'Sharbati' are generally used as a rootstock due to its easy availability and compatibility with commercial peach cultivars. But, this rootstock is highly susceptible to rootknot nematodes. Recently, PAU has released a new rootstock 'Flordaguard' for peach. This rootstock is resistant to root knot nematodes and is also compatible with all the peach cultivars. It can be clonally propagated through rooting of hard wood cutting and ready 
for grafting in short time as compared to propagated via seed. Propagation from cuttings (cloning) produces a plant with the same characteristics as the parent and thus maintains desirable fruiting traits (Hartmann and Kester, 1983). In comparison with other types of cuttings (semi-hardwood, softwood, and so on), hardwood cuttings are easy to take, handle, and store, which allows for flexibility in the preparation of the cutting and, in general, less precision than cuttings that include actively growing tissue (Hartmann et al., 2002).

Propagation through hardwood cuttings is important, particularly in horticulture for mass production at faster rate of improved materials with in short time, cheapest and to perpetuate the characteristics of the parent plant (Hartmann and Kester,1983). Moreover, Indole3-butyric acid is probably the best material for general use, because it is nontoxic to plants over a wide concentration range and is effective in promoting rooting of a large number of plant species (Hartmann and Kester, 1990). The most successful results have been obtained from IBA treatments including auxin hormone group. IBA has been found to be critical for both softwood and hardwood cuttings (Twor- koski and Takeda, 2007; Zenginbal and Ozcan, 2014; Zenginbal et al., 2014; Jana et al., 2015; Ibrahim et al.,2015; Lazaj et al., 2015; Ibironke, 2016; Ari, 2016;). Indole Butyric Acid (IBA) and Naphthalene Acetic Acid (NAA) are synthetic rooting chemicals that have been found to be reliable in the promotion of rooting in cuttings more proficiently than Indole Acetic Acid (IAA) which is a native auxin (Tsipouridis, 2003). Howard (1980) found that different IBA concentrations were optimal for different species.

The objective of present investigation is to induced rooting and vegetative growth in the stem cuttings of Flordaguard rootstock of peach which is nematode resistant by treating its cutting with auxin type growth regulators is to cut short the time of development of rootstock of peach ready for budding/grafting in one year instead of two years as raised through seed.

\section{MATERIALS AND METHODS}

The present study was conducted at PAU, Regional Research Station, Gurdaspur during the years 2012-13 and 2013-14. The hardwood cuttings of 10 years old Flordaguard peach(Prunus persica L.Batch) plant having $15-20 \mathrm{~cm}$ in length and $0.8-1.2 \mathrm{~cm}$ in diameter with 6-7 buds were prepared in the first fortnight of January(2012-13 and 2013-14) .The basal portion of the cuttings was dipped in different doses of Indole-3butyric acid (IBA)viz. 1000ppm, 2000ppm, 3000ppm, 4000ppm, 5000ppm and control (without IBA treatment) for 1-2 minutes .After these treatments, the hard wood cuttings were planted at a distance of $15 \mathrm{~cm}$ in rows, which are kept $30 \mathrm{~cm}$ apart in the well prepared nursery plots by following the recommended package of practices used for proper care of nursery plants. The data on sprouting, rooting, survival and different vegetative growth parameters was recorded and analyzed with Randomized Block Design as described by Gomez and Gomez (1984).

\section{RESULTS AND DISCUSSION}

The days taken to sprouting, days taken to rooting,

Table 1. Effect of different treatments of IBA on days to sprouting and rooting, sprouting and survival percentage, plant height and girth, number of branches and leaves.

\begin{tabular}{lcccccccc}
\hline $\begin{array}{l}\text { Doses of } \\
\text { IBA (ppm) }\end{array}$ & $\begin{array}{c}\text { Days to } \\
\text { sprouting }\end{array}$ & $\begin{array}{c}\text { Days to } \\
\text { rooting }\end{array}$ & $\begin{array}{c}\text { Sprouting } \\
\mathbf{( \% )}\end{array}$ & $\begin{array}{c}\text { Survival } \\
(\mathbf{\%})\end{array}$ & $\begin{array}{c}\text { Plant } \\
\text { height }(\mathbf{c m})\end{array}$ & $\begin{array}{c}\text { Plant girth } \\
(\mathbf{c m})\end{array}$ & $\begin{array}{c}\text { Number of } \\
\text { branches }\end{array}$ & $\begin{array}{c}\text { Number } \\
\text { of leaves }\end{array}$ \\
\hline 1000 & 13.25 & 12.00 & 70.00 & 52.15 & 118.50 & 5.33 & 7.00 & 125.35 \\
2000 & 10.33 & 9.15 & 75.33 & 75.00 & 142.25 & 6.85 & 10.23 & 160.00 \\
3000 & 7.05 & 6.00 & 98.45 & 90.55 & 195.45 & 10.50 & 13.50 & 260.4 \\
4000 & 12.50 & 10.33 & 48.25 & 40.25 & 120.00 & 4.50 & 6.55 & 105.75 \\
5000 & 13.75 & 11.25 & 32.65 & 15.25 & 90.75 & 3.15 & 4.25 & 76.15 \\
Control & 24.50 & 21.20 & 10.00 & 4.00 & 32.50 & 2.15 & 2.35 & 22.00 \\
CD(5\%) & 2.15 & 3.24 & 2.96 & 3.31 & 2.87 & 1.16 & 1.77 & 3.68 \\
SE(mean) & 0.67 & 1.01 & 0.93 & 1.04 & 0.89 & 0.36 & 0.56 & 1.15 \\
\hline
\end{tabular}

Table 2. Effect of different treatments of IBA on the leaf length, leaf breadth, leaf weight, rooting percentage, number of roots, root length, root girth and root weight.

\begin{tabular}{|c|c|c|c|c|c|c|c|c|}
\hline $\begin{array}{l}\text { Doses of } \\
\text { IBA } \\
\text { (ppm) }\end{array}$ & $\begin{array}{l}\text { Leaf length } \\
(\mathrm{cm})\end{array}$ & $\begin{array}{c}\text { Leaf } \\
\text { breadth } \\
(\mathrm{cm}) \\
\end{array}$ & $\begin{array}{c}\text { Leaf } \\
\text { weight } \\
\text { (gm) }\end{array}$ & $\begin{array}{l}\text { Rooting } \\
(\%)\end{array}$ & $\begin{array}{l}\text { Number } \\
\text { of roots }\end{array}$ & $\begin{array}{c}\text { Root } \\
\text { length } \\
\text { (cm) }\end{array}$ & $\begin{array}{c}\text { Root } \\
\text { girth }(\mathrm{cm})\end{array}$ & $\begin{array}{c}\text { Root } \\
\text { weight } \\
\text { (gm) }\end{array}$ \\
\hline 1000 & 15.50 & 3.00 & 0.70 & 55.55 & 45.50 & 20.50 & 0.55 & 7.00 \\
\hline 2000 & 17.20 & 3.50 & 0.85 & 75.45 & 58.45 & 30.00 & 0.75 & 10.23 \\
\hline 3000 & 19.55 & 4.12 & 2.00 & 94.45 & 75.33 & 38.00 & 0.98 & 13.50 \\
\hline 4000 & 18.00 & 3.10 & 0.62 & 65.00 & 34.15 & 22.42 & 0.45 & 6.55 \\
\hline 5000 & 16.52 & 2.75 & 0.50 & 60.25 & 25.00 & 16.25 & 0.32 & 4.25 \\
\hline Control & 11.50 & 2.00 & 0.25 & 12.50 & 10.14 & 8.00 & 0.15 & 2.35 \\
\hline $\mathrm{CD}(5 \%)$ & 2.63 & 1.22 & 0.49 & 2.98 & 2.83 & 3.39 & 0.16 & 1.77 \\
\hline SE(mean) & 0.82 & 0.38 & 0.15 & 0.93 & 0.89 & 1.06 & 0.05 & 0.56 \\
\hline
\end{tabular}


sprouting percentage, survival percentage, plant height, plant girth, number of leaves, leaf length, leaf breadth, leaf weight, rooting percentage, number of roots ,root length, root weight, root girth and number of branches Flordaguard peach (Prunus persica L. Batch) plant were influenced by different levels of IBA concentrations.

Days taken to sprouting and rooting; sprouting and survival percentage: It was observed from the table 1 that the hardwood cutting treated with 3000 ppm IBA concentrations took minimum duration in sprouting (7.05days) and rooting(6.0days) where as these had taken longest duration in control. Similarly, the cutting treated with $3000 \mathrm{ppm}$ IBA gave highest sprouting $(98.45 \%)$ and survival $(90.55 \%)$ as compared to the rest of the treatments. It is due to more number of roots and these parameters decreases with increase in IBA concentrations above $3000 \mathrm{ppm}$. These results are also supported by Ishtiaq et al. (1989) who observed the positive association relating to root formation and bud sprout in peach cultivar Peshawar local. These results supported the findings of Singh et al. (2011) who reported high sprouting percentage $(100.0 \%)$ in cuttings of Bougainvillea when treated with $3000 \mathrm{ppm}$ IBA. Melgarejo et al. (2008) also showed that in pomegranate, the increment in the percentage of cuttings that rooted occurred in most of the clones using low IBA application concentration (3000 ppm). Similarly, Ari (2016) noted the $94.40 \%$ survival in native Vitex agnus -castus 1 . cuttings treated with $3000 \mathrm{ppm}$ IBA.

IBA $1000 \mathrm{ppm}$ is more effective for inducing lesser number of days to sprouting (5.30) with more number of sprouts buds/cuttings (3.60) in Bougainvillea spectabilis cuttings reported by Mehraj et al.,(2013). Better rooting was associated with better survival rate in Prunus cerasus (Prizhmontas, 1991) and in peach cultivar Fertilia (Bertolini, 1994). The logical conclusion seems that large numbers of roots are associated with adequate nutrient absorption which account for ultimate survival. The highest survival percentage (90.0\%) was observed on full-leaf cuttings of Camellia sinensis (L.) O. Kuntze treated with 6000 ppm IBA (Zenginbal et al., 2014).. Bougainvillea stem cuttings showed the maximum percentage of success $(95.60 \%)$ when treated with 400 ppm IBA (Sultana et al., 2016). Sahariya et al. (2013) noted that in Bougainvillea (var. Thimma), IBA at 2000ppm concentration was found much better with 63.33 per cent success in stem cuttings.

Plant height, plant girth, number of branches, number of leaves, leaf length, leaf breadth and leaf weight: Plant height $(118.50 \mathrm{~cm})$ was also significantly higher at $0.89 \%$ level in cuttings treated with IBA $3000 \mathrm{ppm}$ and decreased with increase in IBA concentration. While it was noticed lowest $(32.50 \mathrm{~cm})$ in control(Table1). These results of the present study are in agreement with Noor et al. (1995), who reported that cuttings of apple rootstock M-26 and M-27 treated with IBA at 3000 ppm increased shoot length. Khajehpour et al. (2014) also noted that cutting of olive cultivar coratina treated with $3000 \mathrm{ppm}$ was found to be best in terms of number of roots(8.52), the percentage of rooted cuttings $(84.50 \%)$, branch length $(17.70 \mathrm{~cm})$ and root fresh weight $(10.32 \mathrm{gm})$ in cuttings of Olive (Olea europaea Var Manzanilla).

Plant girth $(10.50 \mathrm{~cm})$ was also significantly higher in the cuttings treated with $3000 \mathrm{ppm}$ IBA (Table1). Highest plant diameter $(2.40 \mathrm{~mm})$, numbers of leaves (16.26) and leaf area $\left(36.42 \mathrm{~cm}^{2}\right)$ were observed in the treatment IBA $5000 \mathrm{ppm}$ in semi-hard wood cuttings of Olive (Thakur et al.,2016). Survival percentage of cuttings $(71.57 \%)$ was also highest in semi-hard wood cuttings of Olive treated with IBA @ 5000 ppm (Thakur et al.,2016).

Number of branches (13.50), number of leaves (260.40), leaf length $(19.55 \mathrm{~cm})$, leaf breadth $(4.12 \mathrm{~cm})$ and leaf weight $(2.0 \mathrm{gm})$ were also significantly higher at 3000 ppm IBA treatments and these above said parameters decreased with increase in IBA concentration above 3000ppm (Table1 and Table 2). Similarly IBA $3000 \mathrm{mg}$ per litre is significantly superior in producing leaf number (9.56 leaf/plant), shoots number (3.92 shoot/plant), and vegetative dry weight ( $2.82 \mathrm{~g} / \mathrm{plant})$ in stem cutting of Ligustrum ovalifolium (Hammo et al., 2015).

In Bougainvillea (var. Thimma), IBA at 2000ppm increased the length of shoots per cutting after one month $(3.07 \mathrm{~cm})$ and length of shoots per cutting after two month $(14.73 \mathrm{~cm})$ (Sahariya et al., 2013). These results are in conformity with the findings of Panchal et al. (2014) that maximum plant height $(16.70 \mathrm{~cm})$, root length $(18.97 \mathrm{~cm})$, number of leaves (14.67),number of branches (3.53) and leaf area (14.80 $\mathrm{cm}^{2}$ ) were observed in cutting of Khirni (Manilkara Hexandra) with 2000ppm IBA. This may be due to IBA that produced healthier lengthy roots and hence absorbed more nutrients and water contents that have great influence on the number of leaves produced by the plant.

Similarly, Lalramhluna and Prasad(2016 reported that with the application of IBA 2000ppm to the air layers of Lemon (Citrus limon L. Burm.) produced high number of bud initiation (17.33), number of leaves $(107.33)$, leaf area $\left(38.37 \mathrm{~cm}^{2}\right)$, number of branches (6.33), length of branches $(106.33 \mathrm{~cm})$ and canopy of plants $(73.33 \mathrm{~cm})$.

The increase in shoot diameter might be due to more number of leaves and it may be due to vigorous root system which enhanced the absorption of minerals and water from the soil resulted in more carbohydrate production and assimilation and enhanced vegetative growth. The increase in leaf area in terms of length and breadth, increases the photosynthetic activity resulting into increased carbohydrates which results in high 
growth. Shahab et al. (2013) also reported that IBA $(10 \%)$ promotes leaf area $\left(26.03 \mathrm{~cm}^{2}\right)$ in terms of length and breadth, sprout length $(18.09 \mathrm{~cm})$, stem diameter(14.44mm), number of roots (15.61), root diameter $(3.41 \mathrm{~mm})$, number of leaves $(17.27)$, root $(14.24 \mathrm{~cm})$ and survival percentage $(70 \%)$ in hardwood cuttings of Alstonia. Mehraj et al. (2013) reported that Bougainvillea spectabilis stem cuttings treated with 1000 ppmIBA was performed as the best in terms of minimum number of days taken to first rooting (4.0) and with highest number of leaves/cutting (35.20), length of sprout $(15.0 \mathrm{~cm})$ and number of branches/ cutting (4.70). Similarly, maximum survival (95.6\%) and shoot length $(55.50 \mathrm{~cm})$ were observed in hardwood cuttings of Ficus religiosa L. treated with $1000 \mathrm{ppm}$ of IBA (Salmi and Hesami,2016).

Similar results were found in Rose cuttings treated with $1000 \mathrm{ppm}$ of IBA had shown significant positive effects on shoot fresh weight $(2.05 \mathrm{gm})$ and shoot dry weight(0.61gm), leaf number (56.50)and shoot length $(14.4 \mathrm{~cm})$ ( Yeshiwas et al., 2015).

Percentage rooting, number of roots, root length, root girth and root weight: Percent rooting (94.45\%) and average number of roots(75.33) were significantly higher in $3000 \mathrm{ppm}$ IBA as compared to the rest of the treatments (Table 2).These results are supported with the findings of Rufato and Kersten (2000), who noted that $3000 \mathrm{pm}$ IBA gave the highest percentage $(70.54 \%)$ of rooted cuttings of Esmeralda peach. These results are in agreement with Swedan et al. (1993), where they reported that hard wood cuttings of plum, peach and GF677 peach rootstock treated with 3000 ppm IBA gave the highest rooting percentage (100\%). Similarly, 3000 ppm IBA increased the number of roots (8.52), the percentage of rooted cuttings (84.50), branch length $(17.70 \mathrm{~cm})$, and root fresh weight (10.32gm).in cuttings of Olive (Olea europaea var. Manzanilla) (Khajehpour et al., 2014). Singh et al. (2011) also reported the maximum rooting $(100.0 \%)$,sprouting $(100.0 \%)$, length of sprout $(18.77 \mathrm{~cm})$ and number of roots $(21.22)$ in cutting of Bougainvillea glabra at $3000 \mathrm{ppm}$ IBA. Tajbakhsh et al. (2009) also reported that highest rooting percentage $(31.50 \%)$ in apple cuttings was in 3000 ppm IBA. Similarly,the hardwoods cutting of Bougainvillea glabra variety Torch Glory were treated with $3000 \mathrm{mg}$ per litre IBA induced maximum sprouted cutting $(100.0 \%)$,rooting $(100.0 \%)$, length of sprout/cutting $(18.77 \mathrm{~cm})$ and number of roots/cutting (21.22) (Singh et al.,2011). Similarly, Mirabdulbaghi et al. (2011), also observed that concentration of IBA $3000 \mathrm{ppm}$ was found to be best to promote the rooting $(60.0 \%)$ in the hardwood cuttings of natural plum apricot hybrid.

Mehraj et al.(2013) found that treatment of IBA $1000 \mathrm{ppm}$ in Bougainvillea spectabilis stem cuttings increased the number of root/cutting (64.20), number of sub root/cutting $(25.80)$, root length $(33.20 \mathrm{~cm})$, root diameter $(0.51 \mathrm{~mm})$, rooting $(100.0 \%)$ and survival $(100.0 \%)$ of rooted cuttings. Similarly, maximum rooting $(98 \%)$ was observed in hardwood cuttings of Ficus religiosa L. treated with 1000ppm of IBA (Salmi and Hesami,2016). The highest rooting (79.56\%), number of roots (8.33), root fresh and dry weights (361.80 and $244.74 \mathrm{mg}$, respectively), number of buds (5.00) were recorded in Kurdistan 5 genotype of Damask Roses (Rosa damascena Mill.) with $1000 \mathrm{mg}$ per litre IBA. (Nasri et al., 2015). Similarly, Rose cuttings treated with $1000 \mathrm{ppm}$ of IBA had shown significant positive effects on most of the root and shoot parameters including root length $(11.29 \mathrm{~cm})$, number of root per cutting (54.2), root fresh weight $(0.79 \mathrm{gm})$ and root dry weight (0.21gm) (Yeshiwas et al., 2015).

Number of sprouted cuttings (6.29), length and diameter of sprout $(23.77 \mathrm{~cm}$ and $1.52 \mathrm{~cm}$, respectively), number of sprouts, number of leaves and number of roots/ cutting(17.77 and 23.00 and 52.42, respectively), and average maximum length and diameters of roots $(26.33 \mathrm{~cm}$ and $1.33 \mathrm{~cm}$,respectively) were noticed maximum in treatment with 2000ppm IBA in Citrus limon cv. Pant Lemon (Singh et al., 2013). Similarly, in Bougainvillea (var. Thimma), IBA at 2000ppm increased the number of rooted cuttings (6.33), percentage of rooted cuttings $(63.33 \%)$, number of roots per cutting (30.0), length of roots $(12.85 \mathrm{~cm})$ and dry weight of the roots $(0.43 \mathrm{~g}$ ) (Sahariya et al., 2013). Application of IBA with $2000 \mathrm{ppm}$ concentration to pomegranate (Punica granatum L.) air layers produced highest rooting $(91.60 \%)$, number of roots (37.29), root length $(8.04 \mathrm{~cm})$,root diameter $(1.54 \mathrm{~mm})$ and survival (97.67\%) (Tomar and Tomar,2012). Maximum number of branches per plant (8.55), number of roots per plant (23.00), root length $(19.62 \mathrm{~cm})$, root weight $(13.25 \mathrm{~g})$ and plant survival $(85.71 \%)$ were observed in Peach cuttings treated with $2000 \mathrm{mg}$ per litre IBA (Pervez et al., 2007).

The highest root length $(114.40 \mathrm{~cm})$ and root weight $(0.41 \mathrm{gm})$ were observed in Honeysuckle (Lonicera japonica) cuttings treated with $3500 \mathrm{mg}$ per lit IBA (AliKarimian and Bidarnamani, 2015).

Auxin induces root formation by breaking root apical dominance induced by cytokinin (Cline,2000). Seyedi et al (2014) noted that stem cuttings of Bougainvillea glabra L.treated with IBA hormone concentrations $4000 \mathrm{ppm}$ induced maximum rooting (93\%), root length $(36.0 \mathrm{~cm})$ and root number(9.0). Similarly, the highest number of roots per cutting (43.00), length of roots per cutting $(9.28 \mathrm{~cm})$, diameter of root per cutting $(1.67 \mathrm{~mm})$, percentage of rooted cutting $(88.0 \%)$, number of sprouts per cuttings (4.34) and the minimum (20.66) days taken to callus formation were noticed in IBA $4 \mathrm{gm}$ per litre in Duranta Golden cuttings (Singh et al., 2014). Similarly, maximum sprouting (43.70\%) leaves per plant (63.0), plant height $(37.46 \mathrm{~cm})$, shoots per plant $(13.0)$, leaf area $(19.33$ 
$\left.\mathrm{cm}^{2}\right)$, shoot thickness $(0.57 \mathrm{~cm})$, root length $(11.5 \mathrm{~cm})$ and roots per cutting (13.0) were recorded in cuttings treated with 4000 ppm IBA in stem cuttings of Ficus Hawaii (Siddiqui and Hussain, 2007). Galavi et al. (2013) also reported that IBA 4000 ppm enhanced the maximum number of roots (8.27), root length $(60.05 \mathrm{~cm})$, root fresh $(0.19 \mathrm{gm})$ and dry weight $(0.11 \mathrm{gm})$ in grape cuttings.

The highest number of roots (25.38) and longest root $(23.53 \mathrm{~cm})$ were obtained with $400 \mathrm{ppm}$ IBA in Bougainvillea stem cuttings (Sultana et al., 2016). It could be due to the effect of IBA as it increases cell wall plasticity and cell division stimulates callus development and root growth (Weaver, 1972).

In other studies, IBA 3500ppm and $2500 \mathrm{ppm}$ also promotes the rooting $(74.58 \%)$ and $86.10 \%$ in the hardwood cuttings in olive (Maghsudlu et al., 2013) and in peach rootstock GF-655 (Ahmed et al., 2003) respectively. Similarly, 3000 ppm IBA significantly increased the root length $(38.0 \mathrm{~cm})$, root girth $(0.98 \mathrm{~cm})$ and root weight $(13.50 \mathrm{gm})$. The values of these growth parameters were decreased with increase in IBA concentration above 3000 ppm (Table 2). Similarly, Hammo et al. (2015) observed that the $3000 \mathrm{mg}$ per litre IBA causes significantly increase in rooting percentage $(68.42 \%)$, roots number (5.91 root/plant), longest root $(3.36 \mathrm{~cm})$, roots dry weight $(0.31 \mathrm{~g})$ in stem cutting of Ligustrum ovalifolium . Eri (2016) also noted about $62.20 \%$ rooting in native Vitex agnus-castus cuttings treated with $3000 \mathrm{ppm}$ of IBA. Ahmed Aziz et al. (2010) also reported similar findings in olive, to obtain the most number of rooted cuttings $(60.0 \%)$, the IBA@3000 ppm was found to be best.

The stem cuttings of Rosa centifolia treated with IBA $450 \mathrm{ppm}$ concentration produced maximum shoot length $(10.67 \mathrm{~cm})$, shoot dry weight $(3.02 \mathrm{~g})$, number of roots (14.00), root length $(11.90 \mathrm{~cm})$ and root dry weight (0.50 g) (Akhtar et al., 2015).

Zenginbal et al.(2014) obtained the best results for rooting $(78.30 \%)$, root length $(14.77 \mathrm{~cm})$, root diameter $(1.30 \mathrm{~mm})$ and number of roots $(6.37)$ with cuttings of Camellia sinensis (L.) O. Kuntze treated with 6000 ppm IBA.

IBA promotes the cell elongation which helped in increase in root length. The increase in root girth may be due to more vegetative growth and accumulation of carbohydrates. The increase in root weight is due to more number of roots, highest root girth and length of the roots. IBA helps in mobilizing reserved food material elongation of meristematic cells and differentiation of cambial initials into root primordial (Nanda, 1975). Certain level of endogenous auxin is already present in the cuttings, therefore treating cuttings with IBA could optimize the auxin level in the cutting and consequently improves the percentage of cuttings that rooted (Melgarejo et al., 2008; Saroj et al., 2008; Polat and Caliskan, 2009).
IBA concentration with $2500 \mathrm{mg}$ per litre was recommended for the rooting $(31.48 \%)$, root length $(5.88 \mathrm{~cm})$ and number of roots (7.0) of Azayesh apple rootstocks (Dvin et al., 2011).Increased root length treated with IBA due to the enhanced hydrolysis of carbohydrates, synthesis of new proteins, cell enlargement and cell division induced by the auxins (Strydem and Hartman, 1960). The percentage of rooted cuttings were increased which might be due to the application of proper IBA concentrations resulted high carbohydrate and low nitrogen level lead to more root formation (Carlson, 1929).

The increase of IBA concentration was accompanied by the decreased rooting percentage, suggesting that high IBA concentrations were not suitable for the root formation process (Singh et al., 2003). Although IBA increases the elasticity of cell wall, accerating division, excessive concentration of hormones may inhibit this process (Rahman et al., 2000).Exogenous auxin application in layers during period of active growth(high edogenous auxin levels) could raise the hormone levels above optimal concentrations, leading to decrease in rooting(Moreira et al., 2009). A similar trend was obtained in air layers of Macleania rupestris where concentration higher than $1500 \mathrm{mg}$ per litre. IBA resulted in reduction of dry and fresh weight of roots. (Duran Casas et al., 2013). Researchers believe that high concentrations of auxin can cause damage to the cutting base. Auxin can be effective to rooting cuttings in a certain concentration (not more than 10,000 ppm), depending on the crop and cultivar, and will have an inhibition effect at higher concentrations observed in Stevia (Cerveny and Gibson, 2005). In Azayesh apple rootstocks, rooting decreased by $11.11 \%$ by increasing IBA concentration at $3500 \mathrm{mg}$ per litre (Dvin et al.,2011). Karakurt et al. (2009) reported that the best concentration of IBA for rooting (20\%) was $1000 \mathrm{mg}$ per litre for MM106 apple rootstock but by increasing IBA concentration to $2000 \mathrm{mg}$ per litre and $4000 \mathrm{mg}$ per litre, no rooting occurred. Babashpour-Asl et al. (2012) in evaluating the effect of Indole-3-butyric acid $2000 \mathrm{ppm}$ on the rooting ability of semi-hardwood Bougainvillea ( Bougainvillea glabra ) cuttings found highest number of roots (8.67) with root length (151.42mm).

The hardwood cuttings of Phalsa treated with IBA at 200 ppm concentration recorded the highest values for root and shoot parameters, viz., minimum number of days taken for sprouting (9.34), maximum number of sprouts per cutting (5.30), number of leaves per cutting (8.50), leaf area per cutting $\left(15.72 \mathrm{~cm}^{2}\right)$, leaf chlorophyll content per cutting $(49.78 \mathrm{mg})$, fresh and dry weight of the shoot (25.36 g and $12.82 \mathrm{~g})$, percentage of rooted cuttings (60.0), number of roots per rooted cutting (42.0), length of the longest root per rooted cutting $(26.08 \mathrm{~cm})$, survival percentage of rooted cuttings $(50.0 \%)$, fresh and dry weight of the root $(3.69 \mathrm{~g}$ 
and $1.08 \mathrm{~g}$ ) and percentage of establishment of rooted cuttings in the main field (45.0) (Ratnamala et al., 2014).

Maximum number of sprouted cuttings (7.33), average length of sprout $(20.53 \mathrm{~cm})$, average number of leaves (25.33), percentage of rooted cutting (73.33), number of primary roots (29.26), and average length of roots $(24.88 \mathrm{~cm})$ were noticed in $5 \mathrm{gm}$ per litre concentration of IBA in pomegranate (Punica granatum L.) cultivar Ganesh (Singh, 2014). Similarly, in semi-hard wood cuttings of olive, percent rooted cuttings (53.33), number of primary roots $(6.58)$ and secondary roots $(8.53)$ and diameter $(0.46 \mathrm{~mm})$ were maximum with cuttings treated with IBA at 5000 ppm (Thakur et al., 2016). IBA promote cell elongation which helped in increase in root length. The increase in root diameter may be due to more vegetative growth and accumulation of carbohydrates. In the grafting trial of four rootstocks, viz. Sharbati peach (Pnunus persica), Kabul Green Gage, Kala Amritsari plum (Prunus salicina), and wild apricot (Prunus armeniaca), IBA 3000ppm enhanced the rooting and survival $(88.30 \%)$ in the hardwood cutting of these rootstocks (Bal and Sandhawalia, 2000). There is a strong correlation between number of roots and survival of plants (Ahmed, 2003).

\section{Conclusion}

From the present study it is concluded that the hardwood cuttings of peach cv. Flordaguard treated with $3000 \mathrm{ppm}$ of IBA for 1-2 minutes took the minimum number of days to sprouting (7.05) and rooting (6.0) with highest sprouting percentage (98.45\%), survival percentage $(90.55 \%)$, plant height $(195.45 \mathrm{~cm})$, plant girth $(10.50 \mathrm{~cm})$, number of branches $(13.50 \mathrm{~cm})$, number of leaves (260.4), leaf length $(19.55 \mathrm{~cm})$, leaf breadth $(4.12 \mathrm{~cm})$, leaf weight $(2 \mathrm{gm})$, percent rooting $(94.45 \%)$, number of roots $(75.33)$, root length $(38.0 \mathrm{~cm})$, root girth $(0.98 \mathrm{~cm})$ and root weight $(13.50)$. Therefore, by following this treatment, the plants produced from the hardwood cuttings of Flordaguard rootstock of peach become ready for budding or grafting in the next year .Rooting of hardwood cutting has been successfully tried on the cuttings of other peach cultivar. But, no information is available on the newly released peach rootstock 'Flordaguard' by PAU,Ludhiana which is highly resistant to root knot nematodes disease. Therefore, keeping in view the resistance of 'Flordaguard' rootstock against root knot nematodes and its need in promoting the fast upcoming peach industry, so the protocol is developed to raise the rootstock plant of Flordaguard through cutting which become ready for budding/grafting in the field in one year instead of two years as raised through seed.

\section{REFERENCES}

Ahmed Aziz, K., Amanullah Saifullah, K., Basharat Hussain,
S. and Munir Ahmed, K. (2010). Effect of indole butyric acid (IBA) on rooting of olive stem cuttings. Pakistan Journal of Agricultural Research, 23 (3/4) :91-93

Ahmed, M. S., Abbasi, N.A. and Amer, M. (2003). Effect of IBA on hardwood cuttings of peach rootstocks under greenhouse conditions. Asian Journal of Plant Sciences, 2:265-269

Akhtar, G., Akram, A., Sajjad, Y., Balal, R.M., Shahid, M.A., Sardar, H., Naseem, K. and Shahm S.M. (2015). Potential of plant growth regulators on modulating rooting of Rosa centifolia. American Journal of Plant Sciences, 6: 659-665

AliKarimian, M. and Bidarnamani,F. (2015). Improving the rooting of Honeysuckle (Lonicera japonica) cuttings by using of Indole-butyric acid treatments and different substrates. Journal of Applied Environmental and Biological Sciences, 5(11S):285-290

Annonymous (2010). Package of practises for cultivation of fruits. Punjab Agricultural University, Ludhiana.

Annonymous (2015). Package of practises for cultivation of fruits. Punjab Agricultural University, Ludhiana.

Ari, E. (2016). Effects of different substrates and IBA concentrations on adventitious rooting of native Vitex agnus-castus 1. cuttings. Acta Scientiarum Polonorum Hortorum Cultus., 15(2):27-41

Babashpour-Asl, M., Shakueefar, S. and Valipour, V. (2012). Effects of Indole-3-butyric acid on the rooting ability of semi-hardwood Bougainvillea sp. cuttings. Modern Applied Science, 6(5):121-123.

Bal, J. S. and Sandhawalia, S.S. (2000). Studies on propagation of subtropical plum. Proceed. of the XXV International Horticultural Congress Part 7. Quality of Horticultural Products: Brussels, Belgium. Acta Horticulturae, 517:151-158

Bartolini, G. (1994). Interaction of carbohydrates,rooting and survival of hardwood peach cuttings. Advances in Horticultural Science, 8:131-33

Carlson, M. C. (1929). Micro-chemical studies of rooting and cuttings. Botanical gazette, 87: 64

Cerveny, C. and Gibson, J. (2005). Rooting hormones. Grower 101.CropCultivation.:236-244. Available: www.gpnmag.com/lm.cfm/gp080503

Cline, M.G. (2000). Execution of the auxin replacement apical dominance experiment in temperate woody species. American Journal Botany, 87:182-190

Duran-Casas S., Veloza-Suan C., Magnitskiy S. and Lanchero H.O. (2013). Evaluation of uva camarona (Macleania rupestris Kunth A.C. Smith) propagation with air layering. Agronomia colombiana, 31(1): 18-26

Dvin, S.R., Moghadam, E.G., Neyestani, E. and Mokhtarian, A. (2011). Studies on rooting of Azayesh apple cutting using Indole-butyric acid and media. Asian Journal of Applied Sciences, 4: 780-786

Galavi, M., Karimian, M.A. and Mousavi, S.R. (2013). Effects of different auxin (IBA) concentrations and planting-beds on rooting grape cuttings (Vitis vinifera). Annual Review \& Research in Biology, 3(4): 517-523

Gomez, K.A. and Gomez, A.A. (1984). Statistical Procedures for Agricultural Research $\left(2^{\text {nd }}\right.$ Edn.), John Wiley and Sons Inc., New York, pp.120-60

Hammo,Y.H. , Kareem, B.Z.A., Salih, M.I. (2015). Effect of planting media and IBA concentration on rotting ability of stem cutting of Ligustrum ovalifolium. Zanco. 
Journal of Pure and Applied Sciences, 27(5):63-68

Hartmann, H.T. and Kester, D.E. (1983). Plant propagation, principles and practices Fourth Ed., Prentice- Hill, INC Engleood Cliffs, New Jersy,USA.

Hartmann, H.T. and Kester, D.E. (1990). Plant propagation, principles and practices Fourth Ed., Prentice- Hill, INC Engleood Cliffs, New Jersy,USA.

Hartmann, H.T., Kester, D.E., Davis, F.T. and Geneve, R.L. (2002). Hartmann and Kesters' plant propagation:Princ. $7^{\text {th }}$ Ed. Prentice Hall, Upper Saddle River, NJ.

Howard, B.H. (1980). Plant propagation, East Malling Research Station Report for 1979, Maidstone, Kent.

Ibrahim, M.E., Mohamed, M.A. and Khalid, K.A. (2015).Effect of plant growth regulators on the rooting of lemon verbena cutting. Journal of Materials and Environmental Science, 6 (1) : 28-33

Ibironke,O.A. (2016). Effect of growth promoting substances on selected three ornamental plants. Advances in Crop Science and Technology, 4:3

Ishtiaq, M., Iftikhar, H. and Ayaz, M. (1989). Initiation of roots in peach rootstocks cvs. Peshawar Local and Nemaguard as affected by indole butyric acid. Sarhad Journal of Agriculture, 5:41-45

Jana, B. R., Das,B., Kumar,S.(2015). Efficacy of IBA and determination of cuttings size in Asian Pear (Pyrus pyrifolia L.). International Journal of Plant Research . 5(3): 64-67

Singh, K. K., Choudhary, T., Kumar, P. and Rawa, J.M.S. (2014). Effect of IBA for inducing rooting in stem cuttings of Duranta Golden. Hort Flora Research Spectrum, 3(1): 77-80

Karakurt, H., Aslantas, R., Ozkan, G. and Guleryuz, M. (2009). Effects of Indole-3-Butyric Acid (IBA), plant growth promoting rhizobacteria (PGPR) and carbohydrates on rooting of hardwood cutting of MM106 Apple rootstock. African Journal of Agricultural Research, 4: 60-64

Khajehpour, G. Jameizadeh, V. and Khajehpour, N. (2014). Effect of Different Concentrations of IBA (Indule butyric Acid) hormone and cutting season on the rooting of the cuttings of Olive (Olea europaea var. Manzanilla). International Journal of Advanced Biological and Biomedical Research, 2(12):2920-2924

Lazaj, A., Rama, P., Vrapi, H. (2015). The interaction with season collection of cuttings, Indol Butyric Acid (IBA) and juvenility factors on root induction in Olea europaea L.(cultivar "Kalinjot"). International Refereed Journal of Engineering and Science, 4 (3) :32-38

Lalramhluna, P. and Prasad,V.M.(2016). Effect of different levels of Indole-3-butyric acid on growth, development, survival and establishment of air layered Lemon (Citrus limon L. Burm.) cv. Assam Lemon under Allahabad Agro-climatic Condition. International Journal of LifeSciences Scientific Research, 2(5):599-603

Maghsudlu, M., Afshari, H. and Faraji, A. (2013). The evaluation of the effect of different IBA (indole-3-butyric acid) hormone concentration and different kinds of cutting on rooting of two compatible Olive cultivars cuttings in Golestan Province. Bulletin of Environment,Pharmacology and Life Sciences, 2 (6) : 82- 88

Mehraj, H., Shiam, I.H., Taufique, T., Shahrin, S. and Jamal Uddin, A.F.M. (2013). Influence of Indole-3Butyric Acid (IBA) on sprouting and rooting potential of Bougainvillea spectabilis cuttings. Bangladesh Research Publications Journal, 9(1) : 44-49.

Melgarejo, P., Martinez, J., Martinez, J.J., Martinez-Valereo, R. and Amoros, A. (2008). Study of the rooting capacity of eleven Pomegranates ( Punica granatum L.) clones using plastic to cover the soil. Ciheam-Options Mediterraneennes, 169-179

Mirabdulbaghi, M., Zarghami, R. and Azghandi, A.V. (2011). Propagation of Tanasgol, a Natural PlumApricot Hybrid (Prunus domestica-armenia) Developed in Iran. Trends in Horticultural Research, 1(1):27-31

Moreira, O., Martins, J., Silva, L. and Moura, M. (2009). Propagation of the endangered Azorean cherry Prunus azorica using stem cuttings and air layering. ARHIPÉLAGO Ciencias Biologicas e Marinhes, 26:9-14

Moreira, O., Martins, J., Silva, L. and Moura, M. (2009). Propagation of the endangered Azorean cherry Prunus azorica using stem cuttings and air layering. Arquipelago. Life Mar. Sci., 26: 9-14

Nanda, K.K. (1975). Physiology of adventitious root formation. Indian Journal of Plant Physiology .18:18-90

Nasri, F., Fadakar, A., Saba, M.K. and Yousefi, B. (2015). Study of Indole butyric acid (IBA) effects on cutting rooting improving some of wild genotypes of damask roses (Rosa damascena Mill.) . Journal of Agricultural Sciences, 60(3) : 263-275

Noor, B.S., Rahman, N. and Zubair, M. (1995). Effect of Indolebutyric acid (IBA) on the cutting of M-26 and M27 apple rootstock. Sarhad Journal of Agriculture, 11 (4): 449-453

Panchal, G.P., Parasana, J.S., Patel, S.R. and Patel, M.V. (2014). Effect of different growing medias and levels IBA on growth and development of Khirni (Manilkara hexandra Roxb) seedlings cv. local. Global Journal of Bio-Science and Biotechnology, 3(4):379-383

Parvez, M., Zubair, M., Mir Saleem, Wali, K. and Shah, M. (2007). Effect of indole-butyric acid (IBA) and planting times on the growth and rooting of peach cuttings. Sarhad Journal of Agriculture, 23(3):587-592

Polat, A.A. and Caliskan, O. (2009). Effect of indole-butyric acid (IBA) on the rooting cutting in various pomegranate genotypes. Acta Horticulturae, 818: 187-192

Prizhmontas, T . (1991). Action of auxins on rooting of sour cherry soft wood cuttings. Sadovostavo-Ivinogradarstvo, 4:18-20

Rahman, N., Hussain, I., Imran, M., Jan, T. and Awan A. (2000). Effect of different concentrations of IBA on rooting of litchi (Litchi chinensis) in air layering. Pakistan Journal of Biological Sciences, 3: 330-331

Ratnamala, M., Kumar, B.P., Swami, D.V.and Suneetha, D.R.S. (2014). Effect of auxins and type of cutting on propagation of phalsa (Grewia subinaequalis DC.) under shade net condition. Green Farming, 5 (3) : 419-423

Rufato, L. and Kersten, E. (2000). Rooting of cuttings of peaches ( Prunus persica (L.) Batsch) cv. Esmeralda and BR2 exposed to stratification and indole butyric acid. Revista Brasileira de Fruiticultura, 22:191-194

Sahariya, K., Singh, J.N. and Singh, A.(2013). Studies on the effect of IBA on rooting of bougainvillea (var. Thimma) cuttings in open field and polyhouse conditions. The Asian Journal of Horticulture, 8(1):140-142

Salmi, M.S. and Hesami, M. (2016). Time of collection, 
cutting ages, auxin types and concentrations influence rooting Ficus religiosa L. stem cuttings. Journal of Applied Environmental and Biological Sciences, 6(1):124-132

Saroj, P.L., Awashi, O.P., Bhargava, R., Singh, U.V. (2008). Standardization of pomegranate propagation by cutting under mist system in hot arid region. Indian Journal of Horticulture, $65: 56-68$

Seyedi, A., Esmaeili, A., Ali Zadeh, K.N. and Porsiabidi, M.M.(2014). Comparative evaluation of the rooting in cuttings in (Bougainvillea glabra L.) International Journal of Farming and Allied Sciences, 3 (8): 872-875

Shahab, M., Ayub, G., Rahman, A., Rashid, A., Jamal, A. and Ali, J. (2013). Assessment of IBA (Indole Butyric Acid) levels and planting time for rooting and growth of Alstonia Cuttings. Journal of Natural Sciences Research, 14(3):59-67

Siddiqui, M.I. and Hussain, S.A. (2007). Effect of indole butyric acid and types of cuttings on root initiation of Ficus hawaii. Sarhad Journal of Agriculture, 23(4):919-925

Singh, S., Kumar, P. and Ansari, S.A. (2003). A simple method for the large-scale proparation of Dendrocalamus asper. Sci. Hortic-Amsterdam, 100: 251-255

Singh, K.K., Rawat, J.M.S. and Tomar, Y.K. (2011). Influence of IBA on rooting potential of Torch Glory Bougainvillea glabra during winter season. Journal of Horticultural Science \& Ornamental Plants, 3(2):162-165

Singh, K.K.(2014). Effect of IBA concentrations on the rooting of pomegranate (Punica granatum L.) cv. Ganesh hardwood cuttings under mist house condition. Plant Archives, 14(2):1111-1114

Singh, K.K., Choudhary, T. and Kumar, K. (2013). Effect of IBA concentrations on growth and rooting of Citrus limon cv. Pant Lemon cuttings. Hort Flora Research Spectrum, 2(3):268-270

Strydem, D.K. and Hartman, H.T. (1960). Effect of indole butyric acid and respiration and nitrogen metabolism in Marianna 2624 plum softwood stem cuttings. Proceedings of American Society for Horticultural Science, 45 $(1-2): 81-82$
Sultana, Z., Akand, M.S.H. and Patwary, N.H. (2016). Rooting performance of stem cuttings of three ornamental plants as influenced by growth regulators. International Journal of Natural and Social Sciences, 3(2): 38-45

Swedan, A.A., Edriss, M.H., Alhamed, A., Yusre, A. (1993) . Root initiation in the plum rootstock Marianna and the promotive effects of co-factors. Egyptian Journal of Horticulture, 20(1):43-55

Tajbakhsh, M., Korkan, M. and Ghiyasi, M. (2009). Effect of timing on callus formation and rooting ability in IBA -treated hardwood stem cutting of Persian walnut, hazelnut and apple. Not. Bot. Hort. Agrobot. Cluj-Napoca, 37: $103-107$

Thakur, M., Sharma, D.D., Babita and Verma, P.(2016). Effect of pre-conditioning treatments and auxins on the rooting of semi-hardwood cuttings of Olive planted during winter under mist condition. Current World Environment, 11(2) :560-566

Tomar, K.S. and Tomar,S.S.(2012). Effect of different dosage of growth regulators on rooting \& survival percentage of pomegranate (Punica granatum L.) air layers. Green Farming, 3(6):701-703

Tsipouridis, C., Thomidis, T. and Isaakidis, A. (2003). Rooting of peach hardwood and semi-hardwood cuttings. Australian Journal of Experimental Agriculture, 43:1363-1368

Tworkoski, T. and Takeda, F .(2007). Rooting response of shoot cuttings from three peach growth habits. Scientia Horticulturae, 115: 98-100

Weaver, R.J. (1972). Plant Growth Substances in agriculture.W.H.Freeman and Company. San Fransisco, p. 504

Yeshiwas, T., Alemayehu, M. and Alemayehu, G.(2015). Effects of Indole butyric Acid (IBA) and stem cuttings on growth of stenting propagated Rose in Bahir Dar, Ethiopia. World Journal of Agricultural Sciences, 11(4):191-197

Zenginbal, H., Haznedar, A. and Dolgun, O.(2014). Effects of Indole-3-Butyric Acid (IBA) and cutting type on rooting of Camellia sinensis (L.) O. Kuntze. American Journal of Experimental Agriculture, 4(12): 1935-1943 